\title{
A Study on Vegetative Propagation of Juvenile and Mature Chrysophyllum oliviforme Trees \\ Ebeid, A. F. A.
}

Dept. of Timber Trees, Hort.Res.Inst., ARC, Egypt.

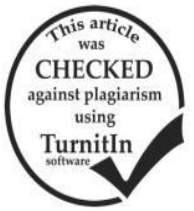

\section{ABSTRACT}

The present work was conducted during 2015 and 2016 seasons at the Tropical Farm, Aswan Botanical Garden, Agric. Res. Inst. to study the possibility of propagated Chrysophyllum oliviforme L. vegetatively. Semi -hardwood cuttings from juvenile ( 3 years old) and mature ( 30 years old) $C$. oliviforme trees were used to test their prospect to form the adventitious roots. The growth media consisted of 2:1 peat: perlite (v: v) ratio and the base of cuttings were soaked for $24 \mathrm{~h}$. in different IBA concentrations $(0,1000,2000,4000$ and $5000 \mathrm{ppm})$. The obtained results showed significant differences in the root and shoot development of cuttings with a higher rooting parameters for the young than mature trees. Using the high hormone concentrations (4000- $5000 \mathrm{ppm}$ ) increased the rooting percentage and growth parameters compared to the low concentrations (1000- $3000 \mathrm{ppm}$ ). However, the anatomy of cuttings postulate that sectors of mature trees had a thicker stripe of xylem vessels and additional cell layers of sclerenchyma than sectors from juvenile trees. Also, cambium was more differentiated with high activity in young trees than in the mature one. You can say that the presence of a continuous sclerenchyma layer can work as a physiological partition to the emerging root and increase with the aging of the tree.

Keywords: Cutting propagation, IBA, Chrysophyllum oliviforme, juvenile, stem anatomy.

\section{INTRODUCTION}

Chrysophyllum oliviforme L. (stainleaf) belongs to family Sapotaceae, the species is cultivated in many of tropical countries as ornamental tree and it lives wild in a region of Hawaii and French Polynesia (Pacific Island Ecosystems at Risk, 2002). Its wood is hard, heavy, strong and has a specific gravity of 0.9 . The tree is used for construction in Cuba (Little and Wadsworth, 1964). It has been extensively used as an ornamental in Florida, Hawaii, and elsewhere. The tree makes a beautiful addition to the natural landscaping, a good basically plant, and an attractive garden, street, and parking lot tree. It may be necessary to maintain a single stem and removal of drooping branches by pruning (Gilman and Watson, 1993). Also they pointed out that C. oliviforme was propagated vegetatively by using misted hardwood cuttings and air layers, both treated with 0.3 percent IBA (indole-butyric-acid). They added that tree production is by the seed and softwood cuttings under mist (Gilman and Watson, 1993). Propagation by seed is a confirmed method for establishing large plantations of Chrysophyllum oliviforme trees in Aswan, Egypt. On the other hand, vegetative propagation from superior specimens of this species resulted in selection and genetic improvement. Also, using vegetative propagation has the advantage of mass production, uniformity of vigor trees in a shorter time, propagating the exact replica of the parent species, the cloning of trees with important characteristics (Beardsell, 1985) and maintaining the genetic purity (Hartmann et aI. 1990). Uniformity character can be produced with cuttings from one selected clone at a given age, having the same diameter and height. These trees are much sought after, especially for wood properties and production. In addition, vegetative propagation leads to the opportunity for close matching of a selected clone to the special characteristics of a particular locality and is of great importance from a silvicultural point of view (Eldridge et aI., 1994).

In the tree improvement programs, rooting of cuttings is one of the most preferred methods (Libby and Rauter, 1984). There are many factors play an important role on the success of rooting of cuttings as early selection of desired characters, age and the environmental interactions (Ali and El-Tigani, 2007). Rooting of cuttings from the wooden trees pointed out that the lignifications degree in the primary phloem affects the rooting succeed of cuttings from trees by hindering the root primordial tissue to the root initials development (Ali, 1986). In this respect, Ali and ElTigani (2007) studied the vegetative propagation of Acacia nilotica by using stem cuttings from nursery seedlings and trees concluded that IBA at 10, 20, 50 and $100 \mathrm{mg} / \mathrm{l}$ improved the rooting ability in young and mature cuttings. Also, Carpenter et al. (1984) used IBA at 8000 ppm to root "new green stem" cuttings taken from juvenile red alder trees (4-to 5-year-old). They obtained enough rooted cuttings for their experiment. Radwan et al. (1989) show that red alder propagated by using semi- hardwood cuttings from shoots of young trees and epicormic sprouts of older trees, especially when IBA is applied. Using epicormic sprouts obtained from mature trees of proven performance will allow cutting propagation of presumably superior trees. Catherine et al. (2010) revealed that Khaya senegalensis saplings are amenable to clone propagation, allowing screening from multiplication and seedling populations of eventual resistant genotypes by semi-hardwood cuttings. Also, it can be summarized that seedlings and saplings have comparable growth patterns. Moreover, juvenile cuttings of Tabebuia heterophylla trees posses the ability to produce more roots compared with that of older cuttings as well as produces a larger root ball; these cuttings have a higher ability to survive (Awang et al., 2011).

The weakness of the ability to rooting of plant species has been attributed to the presence of growth inhibitors (Ooyama, 1962), little or hormonal imbalance or rooting cofactors and the presence of natural barriers (Edwards and Thomas, 1980). There is numerous anatomical studies show that a relationship between the difficulty in rooting and the presence of a pericyclic 
sclerenchyma layer (Beakbane, 1969). Edwards and Thomas (1980) suggest that the presence of a continuous sclerenchyma layer functions as a physiological constraint to adventitious root initiation or as a mechanical barrier to root emergence. Hicks and Gladstone (1971) pointed out that the density and occurrence of sclerenchyma cells in the cortex of cuttings for Populus tremuloides Michx. was found to increase with tree age. They added that when subject to favorable rooting conditions, cuttings from mature trees failed to form root primordia, while those from juvenile root suckers succeeded. Hackett (1985) pointed that nutritional status, environmental and genetic factors affect the length of the juvenile periods. Trees reach to the stage of maturity goes hand in hand with a decline in the growth rate during the post embryonic juvenile vegetative phase to the adult reproductive phase, increased plagiotropism, and changes in reproductive competence, branching characteristics and foliar morphology. On the other side, there are many physiological, biochemical and anatomical changes with the move to the adult phases (Greenwood and Hutchinson, 1993; Husen and Pal, 2006). Husen and Pal (2006) on the anatomical characteristics of shoot for Tectona grandis shows that there are significant differences between them and found that variations in the anatomy of shoot can be used as an indicator of juvenility/maturity in teak. Accordingly, the purpose of this research was designed to study the effect of age of the tree and the IBA concentrations on adventitious root formation in semi hardwood cuttings of Chrysophyllum oliviforme. Also, the anatomical features of sapling and mature tree shoots were studied to determining if these could be used as markers of maturity in these trees.

\section{MATERIALS AND METHODS}

The experiment was carried out during February of 2015 and 2016 seasons at Kom- Ombo Tropical Farm, Aswan Botanical Garden, Aswan Governorate, Egypt to study the impact of age of trees and IBA concentrations on the rooting capability of cuttings for Chrysophyllum oliviforme $\mathrm{L}$.

\section{Procedures:}

Cuttings were prepared from mature (30 years old) and saplings (3 years old) Chrysophyllum oliviforme L.; these trees were located in the tropical farm and they were selected on the basis of excellence in important traits such as growth faster and straightening the tree trunk. Semi-hardwood cuttings were taken from lateral branches; cuttings were 12$15 \mathrm{~cm}$ length, $0.5-1.0 \mathrm{~cm}$ diameter, with 4 to 5 nodes; leaves of cuttings were cut in order to reduce evaporation. Cuttings were hormone treated and planted immediately after treatment.

However, pure IBA was placed in $250 \mathrm{ml}$ of alcohol and diluted with distilled water to get the concentrations required for each treatment (1000, 2000, 4000 and $5000 \mathrm{ppm}$ ), then the cuttings were treated by IBA by soaking cutting base in aqueous solution or distilled water (as control) for 24 hours; they were then placed on the growth medium, which previously prepared before the cuttings had been cut. The substrate consisted of 2:1 peat: perlite medium (v: v) proportion and then placed inside $24 \times 24 \mathrm{~cm}$ black polyethylene bags, filling only $75 \%$. The cuttings were individually set in the growth media at approximately $8-10 \mathrm{~cm}$ deep, irrigation has been using a very fine sprayer and put bags on shelves in a Ceram house. The cuttings were covered by plastic and test the moisture of growth medium every few days and have irrigation when necessary.

\section{Experimental design and observations:}

The experiment was sit in a completely randomized design, with 5 IBA concentrations $(0,1000$, 2000, 4000 and $5000 \mathrm{ppm}$ ) and two cuttings type (mature and sapling trees) with three replicates of 8 cuttings per experimental unit, for a total of 240 cuttings by the end of the experiment. Measurements were taken on, number of rooted cuttings, adventitious root number, root length, root dry weight; leaf number and leaf dry weight at 3 months after treatments. Root length was measured along with the three longest roots measured on the cutting. Also, the roots and leaves dry weights produced by the cuttings were recorded after drying the plant parts for $72 \mathrm{~h}$ at $70^{\circ} \mathrm{C}$.

\section{Chemical analysis:}

Chemical analysis of dried samples (at 3 months after treatments) of the basal $2 \mathrm{~cm}$ of cuttings was conducted to determine the total carbohydrates and nitrogen contents. Total carbohydrate content ( $\%$ of dry matter) was calorimetrically determined with the anthrone sulphuric acid according to the method described by Fales (1951). Total nitrogen (\% of dry matter) was also measured using the Kjeldahl method as Hambrick et al. (1991). Then, carbon/nitrogen ratio ( $\mathrm{C} / \mathrm{N}$ ratio) was calculated.

\section{Anatomical study:}

To study the anatomy of the cutting, it was taken 5 cuttings of each age (sapling and mature Chrysophyllum oliviforme trees) were collected and processed for sectioning. It was soaked fresh cutting of stems at least 48 hours in formalin acetic acid alcohol solution and preserved in $70 \%$ alcohol, then dehydrated in ethyl alcohol series. It was taken sectors by using a rotary microtome and stained in safranin and fast green and then mounted in canada balsam (Johansen, 1940). Sectors were examined using a light microscope to view the slides and adjusted to finest resolution. The capture photos using a Nikkon digital camera installed on the microscope eyepiece.

\section{Statistical analysis:}

Data were tabulated and statistically analyzed according to the method by Snedecor (1956), and L.S.D mentioned by Little and Hills (1978).

\section{RESULTS}

The results of indolebutyric acid (IBA) treatments after 3 months on rooting percentage, main root number and length of roots/ cutting among mature and sapling Chrysophyllum oliviforme trees are given in 
Table (1). Cutting from sapling trees demonstrated higher rooting percentage, main root number and main root length than from mature one during the two seasons. On the other hand, IBA treatments were found very effective and the differences between concentrations were significant for root formation in $C$. oliviforme cuttings either for sapling or mature trees. A maximum rooting percentage $(78.01 \%)$ and root number (6.51) was achieved in cuttings from sapling trees with the application of 5000 ppm IBA treatment, while cuttings from sapling trees with $4000 \mathrm{ppm}$ IBA produce maximum of main root length/ cutting $(5.31 \mathrm{~cm})$ as mean of the two seasons.

Table 1. Rooting percentage and number and length of roots per cutting coming from mature or sapling of Chrysophyllum oliviforme, submitted to different concentrations of indolebutyric acid (IBA) during 2015 and 2016 seasons.

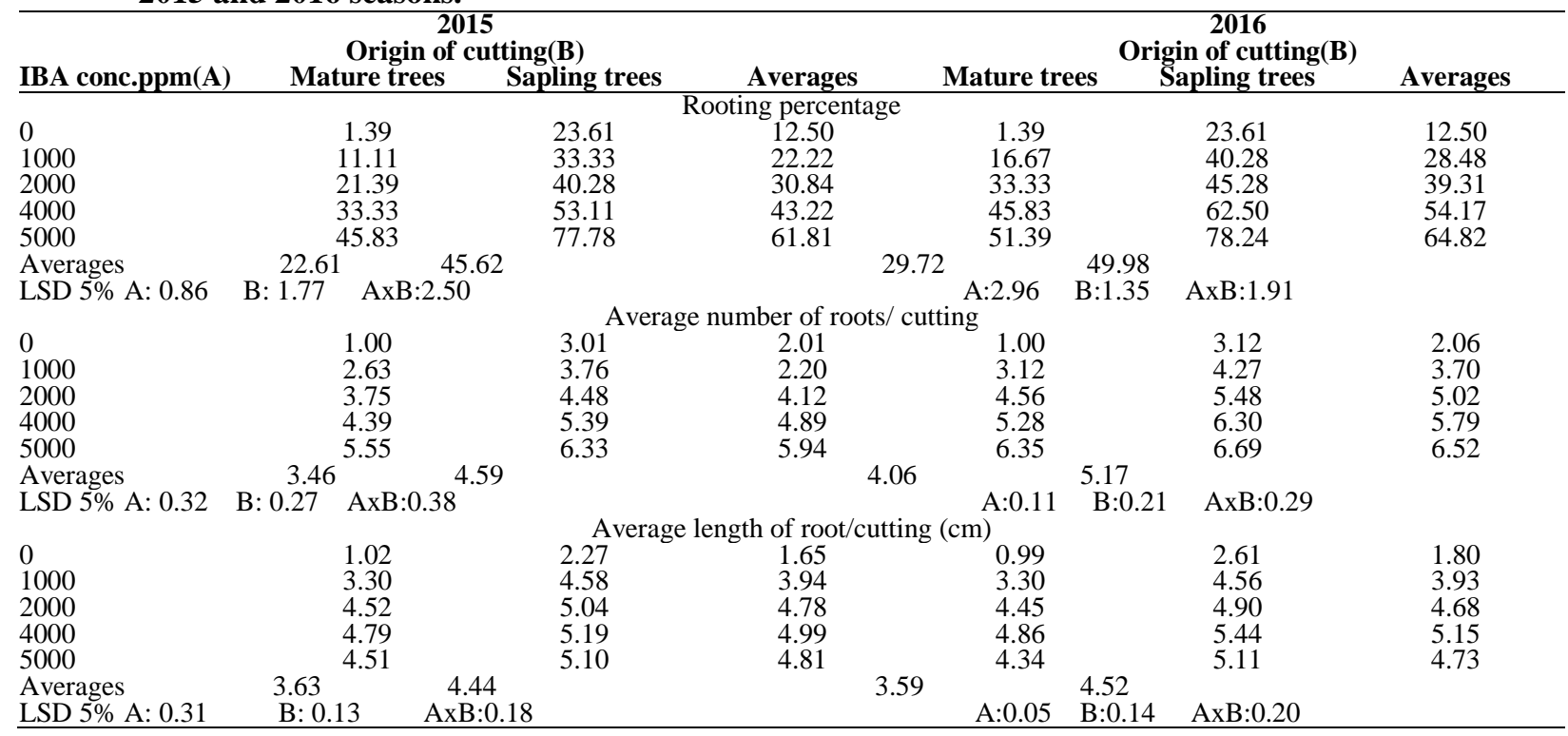

The results of number of leaves and leaves and roots dry weight per cutting coming from mature or sapling of $C$. oliviforme trees, submitted to different concentrations of IBA during are tabulated in Table (2). There were a significant differences in all the attributes measured for different treatments. The concentration of 4000 ppm gave the highest leaves number (4.83) and roots dry weight $(33.50 \mathrm{mg})$, while the highest value (1.48 gm) of dry leaves was recorded with IBA at 5000

$\mathrm{ppm}$ as mean of seasons. Concerning the interaction between the tree age and IBA concentrations and their effects on the number of leaves and leaves and roots dry weight per cutting, the highest value of leaves number and root dry weight was noticed with cutting from sapling trees that applied with IBA at $4000 \mathrm{ppm}$. On the other hand, IBA at $5000 \mathrm{ppm}$ for cuttings from sapling trees produced the best result for the leaves dry weight in the two seasons.

Table 2. Number of leaves and leaves and roots dry weight per cutting coming from mature or sapling of Chrysophyllum oliviforme, submitted to different concentrations of indolebutyric acid (IBA) during 2015 and 2016 seasons.

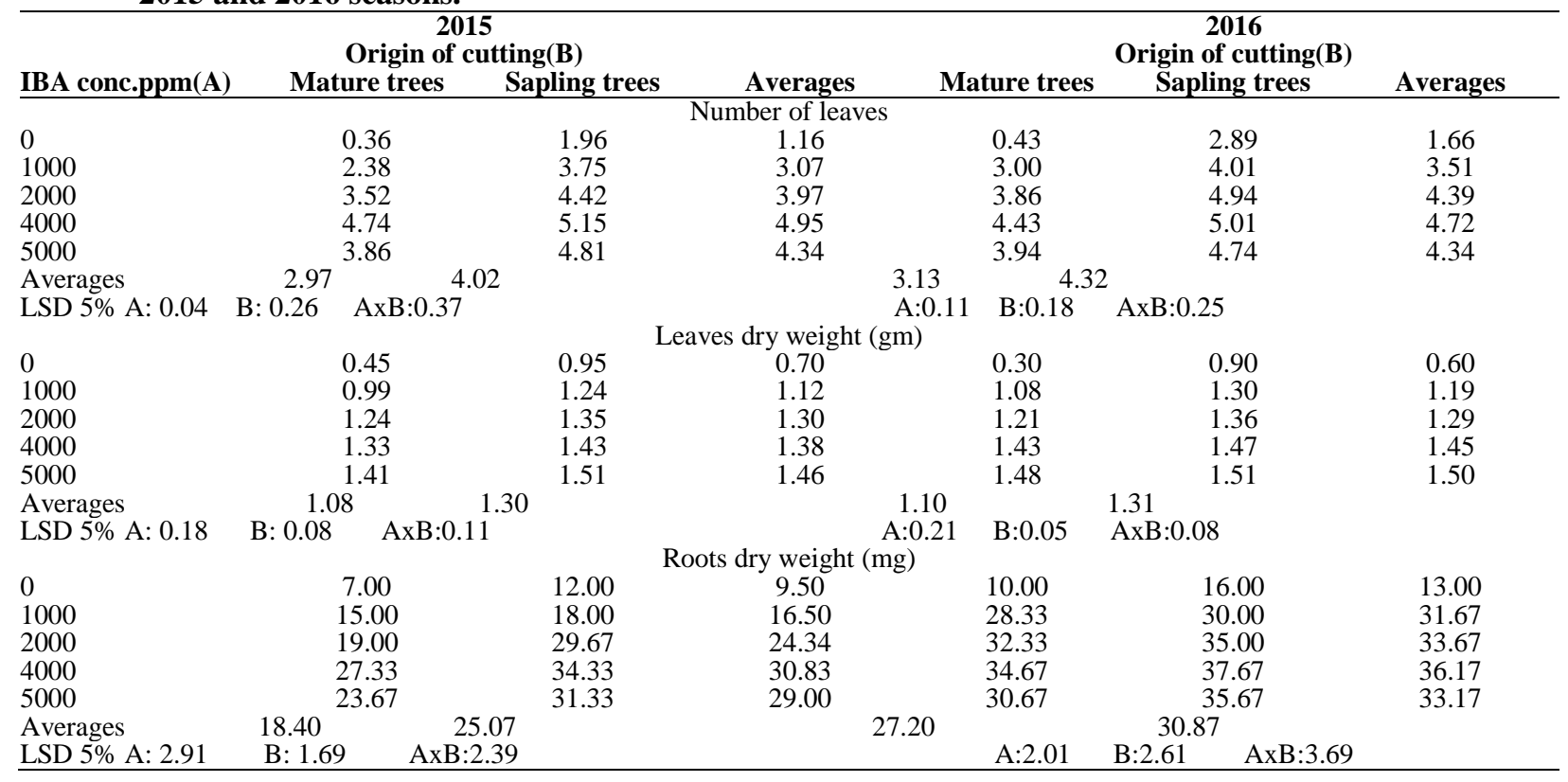


The result from the study indicated that there were significant differences between treatments for nitrogen content, total carbohydrate $\%$ and $\mathrm{C} / \mathrm{N}$ ratio in the cutting base of $C$. oliviforme during the two seasons as shown in Table (3). Also these characters vary with the type of cutting (tree age) and the concentration of IBA treatments. The cutting from sapling trees had higher nitrogen content, total carbohydrate $\%$ and $\mathrm{C} / \mathrm{N}$ ratio however, at $5000 \mathrm{ppm}$; the highest total carbohydrates \% was recorded for the cutting base of sapling trees. The same trends was observed for the average $\mathrm{C} / \mathrm{N}$ ratio, while at $5000 \mathrm{ppm}$ the average nitrogen contents at the cutting base were the lowest for all the stem cutting types. The average nitrogen content was higher in the cutting base without IBA treatment (control) for all the stem cutting types.

Table 3. Nitrogen content, total carbohydrates and $\mathrm{C} / \mathrm{N}$ ratio of the cutting base coming from mature or sapling of Chrysophyllum oliviforme, submitted to different concentrations of indolebutyric acid (IBA) during 2015 and 2016 seasons.

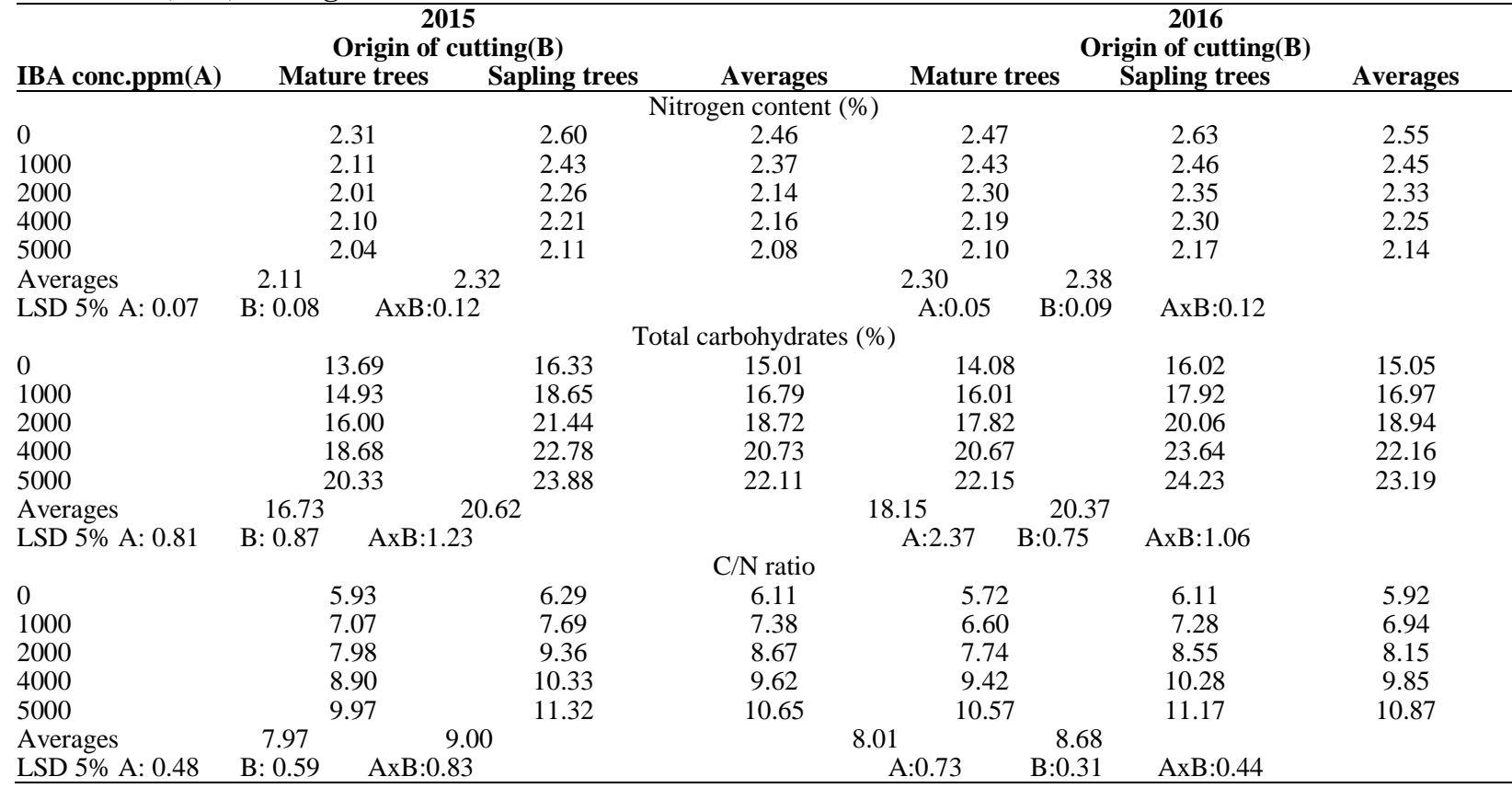

Semi- hardwood cutting from juvenile and mature trees of Chrysophyllum oliviforme showed similar basic anatomical structures (Figs. 1\&2). The stems had a region of central pith, vascular tissue with internal phloem, xylem, cambium and external phloem; this was surrounded by cortical tissue. Moreover, central pith shape is more regular in the sections of cuttings from mature trees. Sections from mature trees had a thicker band of xylem vessels and more cell layers

of sclerenchyma than sections from juvenile trees. Silica is often present in elements, but it was higher in the mature trees than the juvenile one. Also, cambium is more differentiated with high activity in young trees than in the mature one. Cortex tissue in young trees is thicker and ended by a semi- continuous strip of pericycle fibers, while it is less in thickness and ended by batches of pericycle fibers in the mature trees.

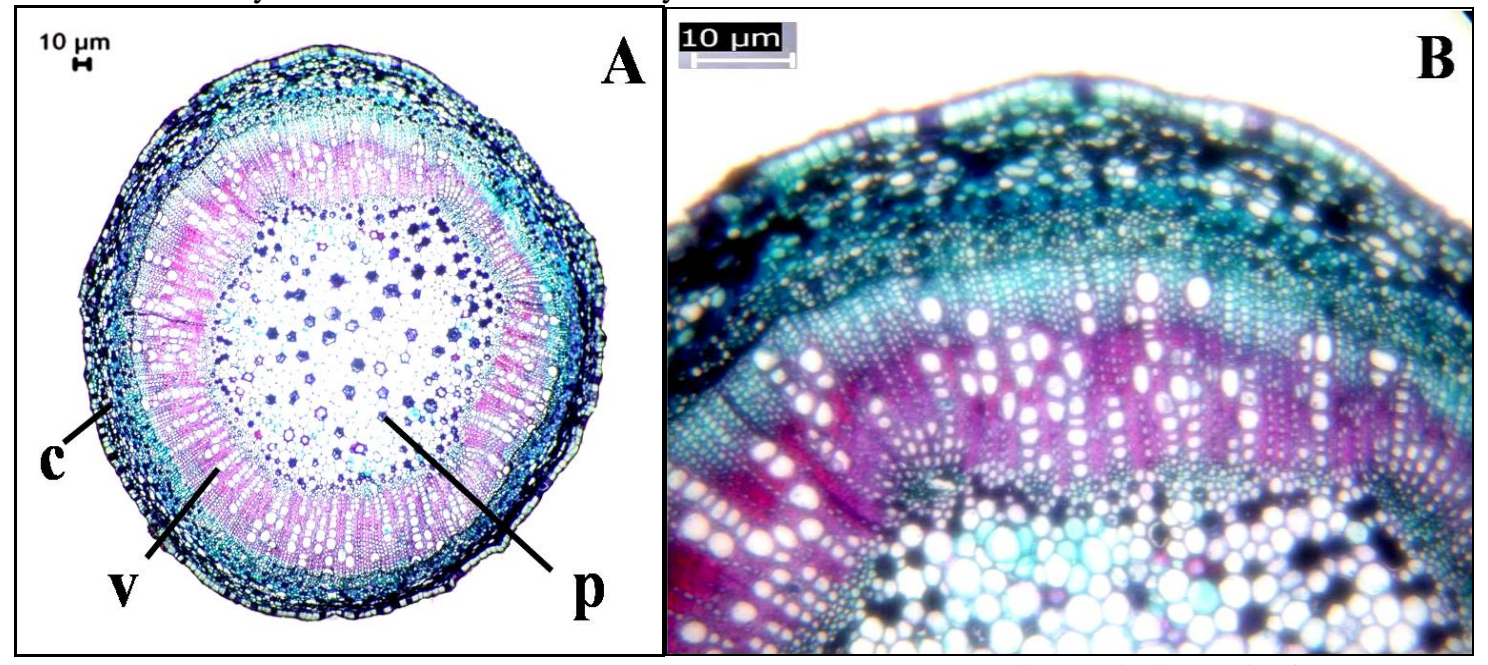

Figure 1. Transverse sections of the semi- hardwood cuttings of young Chrysophyllum oliviforme stock plants ( 3 years old), (A) the general view of the sector; magnification $x=10$ and (B) an enlarged part showing the internal composition of the sector; magnification $x=40$ from the same species, $c=$ cortex; $v=$ vascular tissue; $p=$ pith. Scale bars $=10 \mu \mathrm{m}$. 


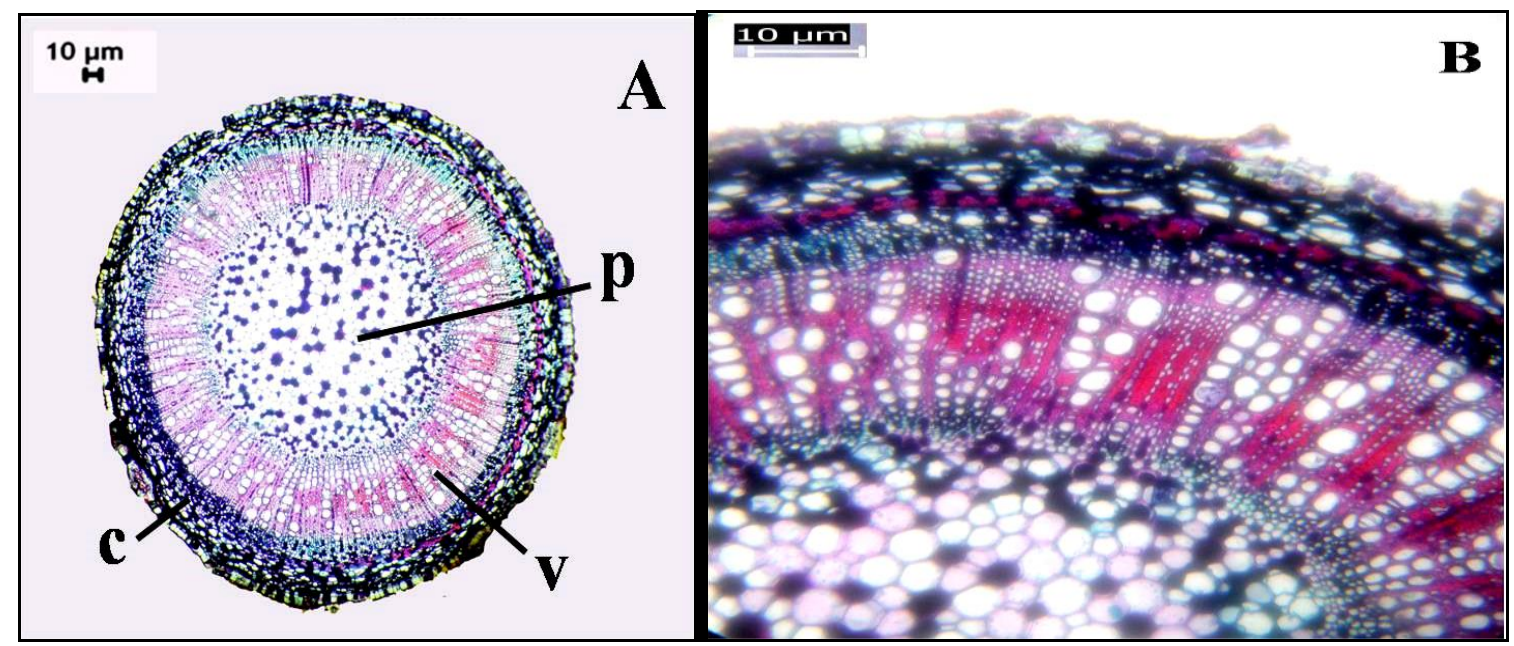

Figure 2. Transverse sections of the semi- hardwood cuttings of mature Chrysophyllum oliviforme stock plants (30 years old), (A) the general view of the sector; magnification $x=10$ and $(B)$ an enlarged part showing the internal composition of the sector; magnification $x=40$ from the same species, $c=$ cortex; $v=$ vascular tissue; $p=$ pith. Scale bars $=10 \mu \mathrm{m}$.

\section{DISCUSSION}

Cutting from sapling trees of Chrysophyllum oliviforme demonstrated higher rooting percentage, main root number and main root length than from mature one during the two seasons. Also, cutting from sapling trees demonstrated higher leaves number and dry root and leaves compared to the mature one. The same trends were observed for the nitrogen content, total carbohydrate $\%$ and average $\mathrm{C} / \mathrm{N}$ ratio. Generally, seedlings of woody plants pass through a juvenile stage before they become matured. These two stages are different in many ways. In some species, they can be easily recognized by morphological differences. Apart from their differences in morphological properties, most woody species are usually capable of exponential increase in size. However, the age of the tree from which cuttings are taken is often one of the most important factors affecting rooting response and early growth. For instance, when cuttings are obtained from trees 10 years of age or less, rooting is usually good; after 10 years it diminishes rapidly, and later more slowly. Rarely is it possible to obtain useful rooting of cuttings from trees older than 80 years (Ruden, 1972). Rooting percentage, root length and number, survival, and growth in and after the year of rooting, all decrease with increasing age of the parent tree (Girouard, 1970b and 1971). The percentage of rooting in the species Karwinskia humboldtiana was higher than that in Karwinskia parvifolia and this was dependent on the age of the plants, the type of stimulator, cutting, substrate, and conditions of cultivation ( Henselova et al., 2002). In Eucalyptus grandis, a juvenile characteristic can be preserved at the base of the plant in juvenile tissue and used in the vegetative propagation of difficult to root mature plants (Huang, 1993; Eldridge et al., 1994). Rooting of cuttings from fir (Abies nordmanniana) trees was greatly reduced with age, while cuttings from the branches decreased less dramatically (Nielsen et al., 2009). However, the success of rooting in the stem cuttings depends upon the physiological condition of the mother plant, its nutritional status and general conditions of growth; type of cutting, pre- treatments and environmental conditions, including the growing season. The emergence of adventitious roots in cutting is basically a phenomenon of differentiation and growth at cellular level. The process of root regeneration is associated with the genetic properties of tree species and status and activities of interior plant hormones (Dhillon et al., 2014).

The higher concentration of IBA (5000 and 4000 ppm) resulted maximum rooting characteristics of $C$. oliviforme, number of leaves and leaves and roots dry weight per cutting as well as the total carbohydrates and $\mathrm{C} / \mathrm{N}$ ratio in cutting base, whereas the lowest value of nitrogen content in cutting base was recorded with the highest IBA concentrations. Improving of adventitious root formation in stem cuttings with plant hormones and commercial rooting media is well known in many plant species those are difficult-to-root (Purohit, 2002). In this respect, Nandi et al. (1997) on Taxus baccata and Nandi et al. (2002) on Cedrus deodara obtained that using IBA was more effective in inducing rooting in stem cutting. In these studies, the rooting percentage was increased as a result of increasing the concentration of plant hormones. Use of rooting hormone is conducive to improve the percentage of rooting and root quality of many of the tree species (Hartman and Kester, 1983). Use rooting hormone can indirectly affect the rooting by improving the speed of transition and movement of sugar to the base of cuttings and consequently stimulate rooting (Haissig, 1974). Also, application of $500 \mu \mathrm{M}$ IBA increased the number of roots on each rooted cuttings as compared with another concentrations applied; this may have an advantage by enhancing good anchorage when planted in the field. Monaco et al. (1980) on their studies of Alnus rubra revealed that cuttings from saplings were rooted well after using 4000 and 8000 ppm IBA treatment. Also, results of Radwan 
et al. (1989) show that red alder can be vegetatively propagated by using softwood cuttings from shoots of young trees and sprouts of older individuals, especially when IBA is employed. Moreover, Salami and Hesami (2016) confirm that taking date and cutting ages affect of Ficus religiosa rooting. Bryant and Trueman (2015) postulated that auxin-treated eucalypt cuttings can produce roots at multiple positions around the vascular tissue. Auxins can be a successful material for increasing rooting ability in cuttings.

The rooting parameters of Chrysophyllum oliviforme cuttings were related to their stem anatomy. The cuttings of mature trees, which have a less ratio and vigor of rooting was more lignified and had a denser ring of sclerenchyma than that of sapling trees for the same species. Pohio et al. (2005) and Hartmann et al. (2011) found that a continuous rings of sclerenchyma are often formed exterior to the region of adventitious root formation as the stem develops; rooting capacity is sometimes negatively associated with the continuity or number of cell layers of the ring (Amissah et al., 2008) It could be argued that there is no direct causal relationship between sclerification and reduced rooting capacity, as adventitious roots can emerge through breaks in the sclerenchyma that form during root or stem growth, and cuttings of species that difficult to rooting often fail to form root primordia irrespective of their sclerenchyma development (Hartmann et al., 2011). Also, Pijut et al. (2011) and Wendling et al. (2014) pointed out that rooting potential may be related to stem anatomy, as soft cuttings often provide higher rooting than semi-firm or lignified cuttings. Cuttings from older stock plants can be more lignified and possess a continuous ring of sclerenchyma that could act as a mechanical barrier to root formation (Maynard and Bassuk, 1996). Therefore, our study pointed out that auxin-treated $C$. oliviforme cutting can produce roots around the vascular tissue especially that from saplings and so propagation methods can aim to produce more roots and leaves.

\section{CONCLUSION}

The study shows that there are differences in the roots and shoot development of the stem cuttings. The age of the trees has a significant effect on the response of rooting of stem cuttings in Chrysophyllum oliviforme. Cuttings from juvenile trees root easily, while the rooting percentage is lower in mature trees. Using of IBA caused a significant effect on the rooting and growth of $C$. oliviforme during the two studied seasons. The most effective concentration of IBA was 5000 ppm; all growth parameters were increased up to the highest concentration (5000 ppm) of IBA. It is also necessary to use the anatomical features of wood like the cortex and vessel tissue as indicator of juvenility and maturity in C.oliviforme. However, more experimental studies are needed to develop specific indicators of maturity and juvenility in these valuable trees.

\section{REFERENCES}

Ali, Y. H. (1986): Vegetative Propagation of some Forest Trees: Structural, Physiological and Biochemical Aspects. M Sc. Thesis University of Khartoum Sudan.

Ali, Y.H. and S. El-Tigani (2007): A Note on the Propagation of Acacia nilotica subspecies nilotca Brenan by Stem Cuttings. Sudan Silva 13 (I).

Amissah, J.N.; D.J. Jr Paolillo and N. Bassuk (2008): Adventitious root formation in stem cuttings of Quercus bicolor and Quercus macrocarpa and its relationship to stem anatomy. J Am Soc Hortic Sci 133:479-486.

Awang, Y.; A. Sandrang; R. Mohamad and A. Selamat (2011): Effect of ontogenic age on root and shoot development of Tabebuia heterophylla cuttings propagated in soilless culture. African Journal of Agricultural Research Vol. 6(24), pp. 5422-5427.

Beakbane, B. (1969): Relationships between structure and adventitious rooting. Combined Proc. Int. Plant Propagators Soc. 19:192-201.

Beardsell, D. (1985): Domestication problems of Australian plants. In: The food potential of seeds from Australian native plants, ed. G.P. Iones, pp. 147-159. Deakin University Press, Victoria.

Bryant, P.H. and S. J. Trueman (2015): Stem Anatomy and Adventitious Root Formation in Cuttings of Angophora, Corymbia and Eucalyptus. Forests 2015, 6, 1227-1238; doi: 10.3390/f6041227

Carpenter, C. V.; L.R. Robertson; I.C. Gordon and D.A. Perry (1984): The effect of four new Frankia isolates on growth and nitrogenase activity in clones of Alnus rubra and Alnus sinuata. Can. J. For. Res. 14: 701-706.

Catherine, K. D.; J. Bayala; M. Tigabu, P. C. Odén and I. J. Boussim(2010): Comparison of Growth Responses of Khaya senegalensis Seedlings and Stecklings to Four Irrigation Regimes. Silva Fennica 44(5).

developmental biology and biotechnology of higher plants. Korean Society of Plant Tissue Culture. 237-254.

Dhillon, H.S.; A. K. Thakur and K. J. Singh (2014): Growth and propagation aspects of some medicinally important trees in Chandigarh, India: a review. Journal of Medicinal Plants Studies , 2(5): 29-35.

Edwards, R.A. and M.B. Thomas (1980): Observations on physical barriers to root formation in cuttings. Plant Prop. 26:6-8.

Eldridge, K.; J. Davidson; C. Hardwood and G. Van Wyk (1994): Eucalypt domestication and breeding, pp. 228-246. Oxford Science Publications, London.

Fales, F.W. (1951): The assimilation and degradation of carbohydrates by yeast cells. J. Bio. Chem., 193213.

Gilman, E.F. and D.G. Watson (1993): Chrysophyllum oliviforme, Satinleaf. Fact Sheet ST-166. Environmental Horticulture Department, Florida Cooperative Extension Service, University of Florida. 2 p.

Girouard, R. M. (1970b): Rooting plain and heel cuttings of spruce. Plant Propag. 16 (1): 7-12.

Girouard, R. M. (1971): Rooting plain and heel cuttings of spruce. Commonw. For. Rev. 50: 28-31.

Greenwood, M.S. and K.W. Hutchinson (1993): Maturation as a developmental process. In: Ahuja, M.R. and W.J. Libby (eds), Clonal Forestry, Vol. 1. Springier- Verlag, Berlin Heidelberg, Now York, pp. 14-33.

Hackett, W.P. (1985): Juvenility, maturation and rejuvenation in woody plants. Hortic. Rev. 7: 109155 . 
Haissig, B.E.(1974): Influences of auxin synergists on adventitious root primordium initiation and development. NZ Journal of Forest Science , 4: 311 323.

Hambrick, C.E.; F.T. Davies and H.B. Pemberton (1991): Effect of cutting position and carbohydrate/nitrogen ratio on seasonal rooting of Rosa multiflora. HortScience 20: 570.

Hartman, H.T. and D.E. Kester (1983): Plant propagationPrinciples and Practices. Prentice Hall, Englewood Cliffs, New Jersy, p. 662.

Hartmann, H.T.; D.E. Kester; F.T. Davies Junior and R.L. Geneve (2011): Plant propagation: principles and practices. Prentice-Hall, New Jersey.

Hartmann, H.T; D.E. Kester and F.T. Davies (1990): Plant Propagation: Principles and Practice. Prentice-Hall, New Jersey.

Henselova, M.; A. Lux and E. Masarovicova (2002): Effect of Growth Regulators on Rooting Cuttings of Karwinskia Species under in vivo Conditions. Rostlinna Vyroba, 48, (10): 471-476.

Hicks, R.R. and W.T. Gladstone (1971): Some anatomical aspects of rooting quaking aspen. Proc. 11th Southern Forest Tree Improvement Conf. p. 265274.

Huang, L. (1993): Phase reversal of trees by shoot tip grafting in vitro. Advances in

Husen, A and M. Pal (2006): Variation in shoot anatomy and rooting behavior of stem cuttings in relation to age of donor plants in teak (Tectona grandis Linn. f.). New Forests , 31:57-73

Johansen, D.A. (1940): Plant Micro-technique. McGrawHill New-York. 523p.

Libby, W. J. and R.M. Rauter (1984): Advantages of Clone Forestry. Scientific and Technical Articles. The forestry Chronicle 145-149.

Little, E.L. and F.L. Wadsworth (1964): Common trees of Puerto Rico and the Virgin Islands. Agric. Handb. 249. U.S. Department of Agriculture, Washington, DC. $548 \mathrm{p}$

Little, I.M. and F.J. Hills (1978): Agricultural Experimentation, Design and Analysis. Johan Wiely and Sons Inc. New York 320 pp.

Maynard, B.K and N.L. Bassuk (1996): Effects of stock plant etiolation, shading, banding, and shoot development on histology and cutting propagation of Carpinus betulus L. fastigiata. J Am Soc Hortic Sci 121:853-860.
Monaco, P. A.; T. M. Ching, and K. K. Ching (1980): Rooting of Alnus rubra cuttings. Tree Planters' Notes. Summer 1980 pp. 22-24.

Nandi, S.K.; H.C. Rikhari; M. Nadeem and L.M.S. Palni (1997): Clonal propagation of Taxus baccata L.- A Himalayan asset under threat. Physiology and Molecular Biology of Plants , 3: 15-24.

Nandi, S.K; S. Tamta and L.M.S Palni (2002): Adventitious root formation in young shoots of Cedrus deodara. Biologia Plantarum , 45(3): 473476.

Nielsen, U.B.; H. N. Rasmussen and M. Jensen (2009): Rooting Nordmann fir cuttings for Christmas Trees. Working Papers of the Finnish Forest Research Institute 114: 48-52

Ooyama, N. (1962): Studies on promotion of rooting ability of the cuttings from tree species difficult to root (in Japanese with English summary). Govt. For. Expt. Sta. Meguro, Tokyo, Bul. No.145.

Pijut, P.M.; K.E.Wowste and C.H. Michler (2011): Promotion of adventitious root formation of difficult-to-root hardwood tree species. Hortic Rev 38:213-251.

Pohio, K.E.; H.M. Wallace; R.F. Peters; T.E. Smith and S.J. Trueman (2005): Cuttings of Wollemi pine tolerate moderate photoinhibition and remain highly capable of root formation. Trees Struct Funct 19:587-595.

Purohit, V.K. (2002): Mass propagation of Banj, Tilonj and Phaniyat oaks.Ph.D. Thesis submitted to H.N.B. Garhwal University, Srinagar (Garhwal), 180 p.

Radwan, M.A.; T. A. Max and D. W. Johnson (1989): Softwood cuttings for propagation of red alder. New Forests 3: 21-30.

Ruden, T. (1972): Propagation of spruce cuttings - method and possibilities in scientific and practical application. Canad. Dep. Environ. Library Transl. OOENV TR-155. 9pp.

Salmi, M.S. and M. Hesami (2016): Time of Collection, Cutting Ages, Auxin Types and Concentrations Influence Rooting Ficus religiosa L. Stem Cuttings. J. Appl. Environ. Biol. Sci., 6(1)124-132.

Snedecor, G.W. (1956): Statistical Methods $5^{\text {st }}$ ed. Iowa State College Press, Ames, Iowa 270 p.

Wendling, I; P. R. Brooks and S. J. Trueman (2014): Topophysis in Corymbia torelliana x $C$. citriodora seedlings: adventitious rooting capacity, stem anatomy, and auxin and abscisic acid concentrations. New Forests DOI 10.1007/s11056014-9451-7.

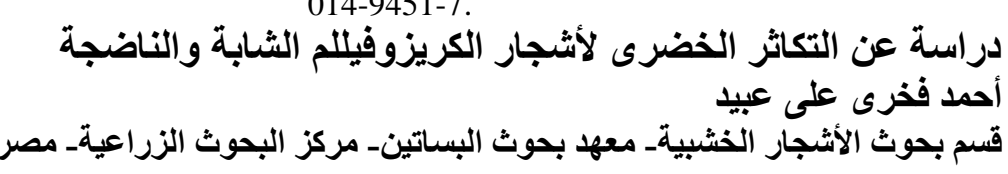

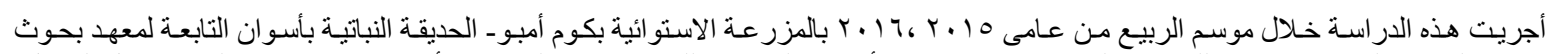

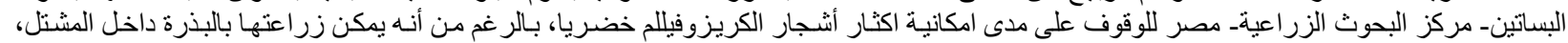

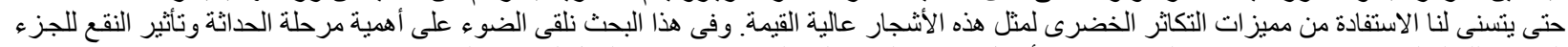

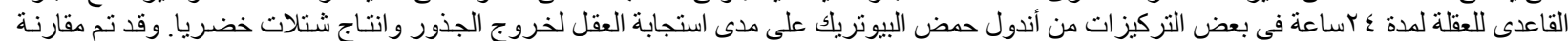

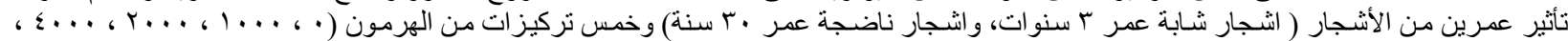

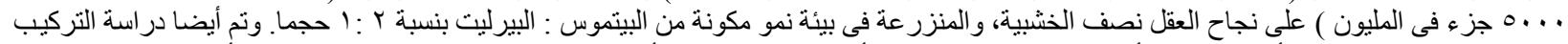

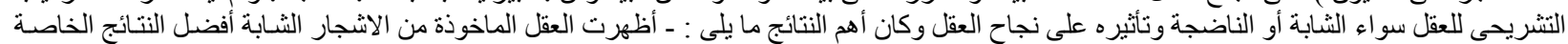

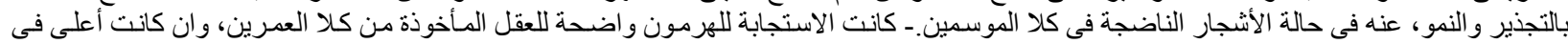

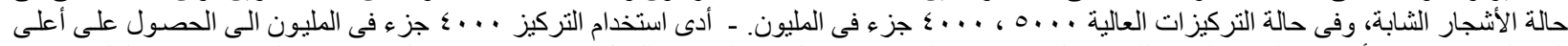

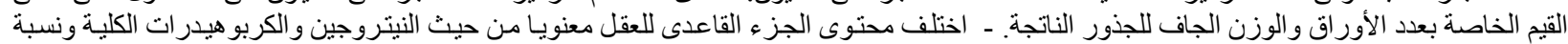

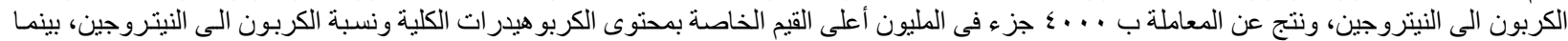

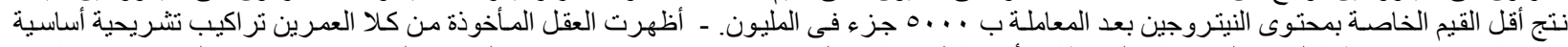

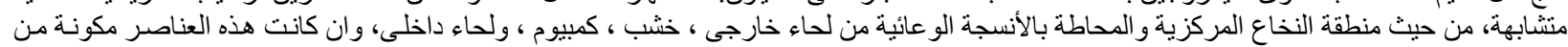

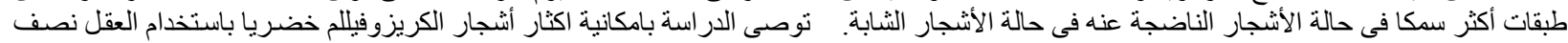

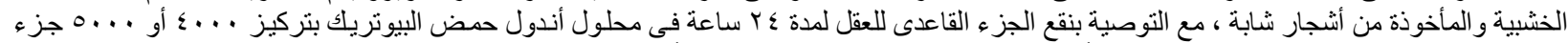

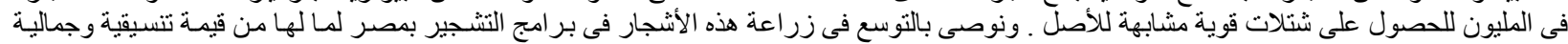

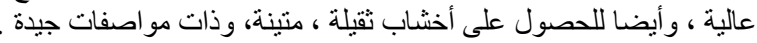


Ebeid, A. F. A. 